\title{
Hierarchical Chain Of Consumer-Based Brand Equity: Review From The Fast Food Industry
}

Tan Teck Ming, Multimedia University, Malaysia

Hishamuddin Bin Ismail, Multimedia University, Malaysia

Devinaga Rasiah, Multimedia University, Malaysia

\begin{abstract}
The aim of the study was to fill in the gaps in the discussion of the way in which fast food brand equity is developed. A proposed conceptual framework - Hierarchical chain of consumer-based brand equity - was postulated based on the casual relationships among dimensions of brand equity. A comprehensive and extensive literature review helped to develop a brand equity framework. In the fast food industry, the dimensions of consumer-based brand equity are decomposed into brand awareness, brand familiarity, perceived quality, brand image, brand trust and attitudinal brand loyalty, demonstrated three-level hierarchical chain. Brand familiarity, perceived quality, brand image, and brand trust were proposed to serve as mediating variables of other constructs, indicating direct and indirect relationships among brand equity dimensions.
\end{abstract}

Keywords: Brand Equity; Fast Food; Brand Familiarity; Brand Trust; Hierarchical Chain

\section{INTRODUCTION}

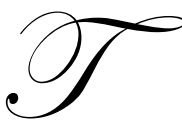

he global fast food market grew by $6.6 \%$ in 2008 to reach a value of $\$ 154.7$ billion. In 2013 , the global fast food market is forecasted to reach \$200 billion, an increase of $29.3 \%$ since 2008 (Datamonitor 2009). Fast food chains were among the many types of restaurants that were interested in building strong brands; however, achieving that goal was not always easy given that many fast food chains' products and services were not inherently differentiated and the channels of distribution were not distinctive. Judy et al. (1999) identified that the fast food industry had heavily relied on price promotions as an important marketing activity; however, such ongoing marketing mechanism was valued as a form of discounting (William, 2003).

Brand name has been seen to be positively associated with consumer product evaluations, perceptions of quality (Rao \& Monroe, 1989), willingness of consumer to pay premium prices (Keller, 1993), repeat purchase (Chiou \& Droge, 2006), low switching to better competitors (Narayandas, 1996), and recommendation to others (Russell-Bennett et al., 2007). In another study, it was proven that children were six times more likely to prefer chicken nuggets and three times more likely to prefer French fries that were presented in McDonald's packaging (Sharma, 2007). Despite these interests, the existing literature on brand equity within the fast food industry was still sparse. There are gaps in brand equity literature as to what was meant by fast food brand equity (Leung \& Bougoure, 2008), what additional dimensions were needed to be highlighted (Tong \& Hawley, 2009), and how it should best be built, implemented and managed (Keller, 2001).

This study was intended to bring contribution toward the theory of service brand equity, specifically in fast food brand equity literature, which has been very limited. The current study provided valuable information in answering and supporting the following research questions: "Are there any pre-determinate constructs among dimensions of brand equity?" "Are there any existing mediating variables in the dimensions of brand equity?" "What are the steps for achieving a strong brand?" "What subsequent benefit(s) could a specific brand construct contribute in the next level of brand equity dimensions?" As an active response to these research questions, brand 
familiarity and brand trust were proposed as additional dimensions, which served as a function in mitigating consumers' negative perceptions during purchase decision or food selection (Morgan \& Hunt, 1994). The study also attempted to fill in relevant gaps in the literature by developing a conceptual framework hierarchical of consumerbased brand equity (Figure 1). It further went on to demonstrate the existence of casual relationships among the dimensions.

\section{LITERATURE REVIEW}

\section{Overall Brand Equity}

In general, brand equity is the incremental utility and value added to a product by its brand name, such as Mercedes-Benz, BMW, Nike, Adidas, Coke, Pepsi, Kodak, Gucci, Louis Vuitton, Levi's, McDonald's, and Starbucks (Burke, \& Oliva, 1993; Farquhar et al., 1991; Kamakura \& Russell, 1993; Rangaswamy, Park \& Srinivasan, 1994). Many measurements of brand equity have been created with respect to different concepts. As a result, a wide spectrum of different perspectives on how brand equity ought to be conceptualized and managed is in play today. Basically, brand equity subsumed to brand value and brand strength (Srivastava \& Shocker, 1991) where it could be classified into two perspectives of measuring; namely, financial (brand value) and consumer-based (brand strength) brand equity.

From a financial perspective, brand equity was sometimes addressed as a firm level approach or companyoriented perspective (Feldwick, 1996). This approach measured the brand as financial assets, which could be defined as either the asset management for manufacturers or leverage for trades. On the other hand, consumer-based brand equity reflected consumer perceived value, which was formed by the combination of a product's functional performance, emotional benefits, and consumer's lifestyle. In other words, Teas and Grapentine (1996) stated that it had derived its importance from the impact of brand based on consumer's evaluation of products or services.

There are two different approaches in the consumer-based perspective, which are economic-based (Erdem \& Swait, 1998) and psychological-based approaches (Aaker, 1991; Keller, 1993; Loken \& Roedder John, 1993). Economic-based brand equity concept addressed the issue of how brand added value for customers (Erdem \& Swait, 1998). Essentially, customers were willing to pay price premiums or become loyal to a brand because their expected utility increased. Psychological-based approaches indicated that the brand was seen as a node in the memory with a variety of different types of associations, varying in strength, linked to it. This approach assumed that consumers saw brands as categories that, over time, had come to be associated with a number of specific attributes, based on the attributes associated with the different products that represented individual members of the brand category (Loken \& Roedder, 1993).

There are numerous concepts and principles from psychology and social cognition in developing models of consumer brand-related decisions, such as affect referral mechanisms, recognition processes, accessibilitydiagnosticity considerations, expectancy value formulations, and so on (Barton \& Robin, 2002). Two wellestablished models of brand equity that rely in various ways on consumer psychology principles in their development are Aaker (1991) and Keller (1993) models. Aaker's (1991) approach was largely from a managerial and corporate strategy perspective, but with underpinning consumer behavior. On the other hand, Keller (1993) approached brand equity as somewhat more of a consumer behavior perspectives.

\section{TO RELATE BRAND FAMILIARITY AS ADDITIONAL DIMENSION}

Interestingly, most of the people have known fast food brands, such as A\&W, McDonalds, KFC, and Pizza Hut, since childhood. Consumers were more familiar with famous fast food brands when compared to well-known product brands, such as Mercedes-Benz, BMW, Nike, Prada or Adidas. This was mainly because fast food was accessible, acceptable and affordable for most of the consumers at anytime and anywhere.

The Daily mail (2010) highlighted that UK Waltham Forest Council had banned fast food outlets from opening within a 400-metre (437 yards) "exclusion zone" around schools, leisure centers and parks. The main reason was to stop the fast food outlets operating next to schools and tempting children away from revamped 
healthier canteen meals. In another study, Singh (2007) stated that in 2007, Malaysia banned fast food advertising for children's programs because fast food was considered "the silent killer", primarily motivated by the increasing number of Malaysians suffering from various kinds of diseases.

Unfortunately, most of consumers did not consider the effects of fast food consumption while making purchase decisions or food selections. Despite the widespread acknowledgement that fast food was unhealthy, the question arises, "Can familiarity of brand mitigate perception of negative effects for fast food consumption and lead to the creation of brand equity?" According to Mano and Davis (1990), the familiarity of fast food brand played an important role in product preference. The role of familiarity also appeared to be far greater for low involvement types of decisions where the consumer looked for a simple rule for decision-making (Batra \& Ray, 1985), such as food.

This could be explained by most of Generation Y who were born between 1982 and 2003 and recognized the fast food brand since childhood as they were frequently exposed to fast food advertising during children's program. Schlosser (2002) expressed that the flavors of childhood food seem to leave an indelible mark and adults often return to them without always knowing why. Laroche et al. (1996) highlighted that familiarity with a brand had increased consumer confidence, attitude toward the brand, enhanced purchase intention, and mitigated the potential negative impact of a negative trial experience (Smith, 1993). Therefore, brand familiarity might serve as a function in mitigating consumers' negative perceptions, such as the effects of consumption while making fast food purchase decisions. Ideally, brand familiarity would transform fast food into "comfort foods" which serves as a source of pleasure and reassurance (Schlosser, 2002).

\section{TO RELATE BRAND TRUST AS ADDITIONAL DIMENSION}

According to Rydell (2008), there were several reasons for dining at fast food restaurants, such as quick, convenient, tasty, inexpensive, too busy to cook a well balanced meal, a "treat" for myself, a way of socializing with friends and family, offers nutritious food, and entertaining. There was high consistency in fast food operations for taste, portion, price, presentation, promotion, services, business hours, environment, facilities, and readily available at any time of the day, and being only a drive through or a phone call away.

For these reasons, consumers would rely on the ability of the brand to perform its stated functions instead of people involved in the restaurants. Consistency of the brands' functions leads to the feeling of security held by the consumer when interacting with the brand. Morgan and Hunt (1994, p. 23) stated that trust existed "when one party had confidence in an exchange partner's reliability and integrity." This was explained by understanding exchange partners directed to the formation of trusted business relationships. Once trust was formed, the relationship between brand and customer had the potential to be mutually beneficial. Trust could be created from an exchange environment in which the fast food brands provided consistent services to its customers across different outlets.

Consequently, consumers had perceptions that the brand was reliable and responsible for their interests and welfare anywhere and at any time. According to Delgado-Ballester (2004), such a situation could be explained as brand trust. Brand trust would lead consumers to consider the benefits at the point of consumption instead of the health effects after consumption.

\section{CAUSAL RELATIONSHIP OF BRAND EQUITY DIMENSIONS}

The dimensions of brand equity were intimately interrelated (Aaker, 1991). However, there are suggestions in the literature that the dimensions could have a potential causal order (Agarwal \& Rao, 1996). Similarly, Yoo et al. (2001) noted a hierarchy of effects among brand equity dimensions. They posited that awareness and associations preceded perceived value and, in turn, influenced brand loyalty.

\section{Brand Awareness}

According to Erdem and Swait (1998), when there was existence of uncertainty about product attributes, brand could be served as a platform to ensure credibility and position of the product by decreasing perceived risk and information costs as identified by consumers. Nevertheless, the reduction of uncertainty led to higher quality 
expectation by consumers (Erdem \& Swait, 1998). According to Dodds, Monroe and Grewal (1991), brand awareness, or brand popularity, could have a positive effect on consumers' perceptions of quality and value because it allows consumers to associate the brand with its product category, as referred to the strength of a brand's presence in the consumers' minds (Aaker, 1996). Grewal et al. (1998) further concluded that brand awareness and perceived quality had a positive and significant relationship in a bicycle brand study.

Researchers stressed that brand awareness was the dominant selection process among consumers and that the higher the brand awareness, the higher the brand familiarity and reputation (Cobb-Walgren et al., 1995; D'Souza \& Rao, 1995; Reynolds \& Olson, 1995). Brand familiarity was formed by the acquired information through external sources, such as advertising, word-of-mouth, and internal sources such as use of the product (Gursoy \& McCleary, 2004). As a result, a consumer's brand awareness would be higher as his or her exposure to the brand increases (Woodward, 2000). This could be supported by Alba and Hutchinson's (1987) argument where a consumer's recognition and recall of a certain brand name would build a sense of familiarity.

As indicated by Keller (1993), he proposed that there were three reasons why brand awareness was important in consumer decision-making. Firstly, it was essential that the brand came to consumers' minds when they thought about the product category. The consequence of high level of brand awareness would place the brand in the consumer's mind set and eventually the decision-making of the consumer (Hoyer \& Brown, 1990; Macdonald \& Sharp, 2000). Secondly, brand awareness affected decisions about brands in the consideration set, even if there were no essential brands associated. Studies indicated that a minimum level of brand awareness could have a significant effect on product purchase decisions, particularly when consumers had low involvement (Hoyer \& Brown, 1990; Petry \& Cacioppo; 1986). Thirdly, brand awareness affected consumer decision-making by influencing the formation and strength of brand associations in the brand image. According to Hoyer and Brown (1990), brand awareness generated differences in information processing and these differences were created by brand associations in the consumer's memory, which directly affected brand image.

Furthermore, Aaker (1991) emphasized that the awareness of the product or brand was the beginning of loyalty. If a customer was aware of a certain product or brand, there was a higher possibility that the customer would have a favorable image of the product or brand. Therefore, positive brand image through high brand awareness, increased the likelihood of brand purchase leading to brand loyalty (Keller, 1993).

Consequently, as Keller (1993) rightly put it, brand awareness affected a consumer's decision-making by influencing the formation and strength of brand associations in the brand image. Therefore, the presumption was that more exposed products and brand names could create a favorable brand image which, in the long run, led to brand loyalty since consumers were likely to buy a certain product or brand that had a favorable brand image. This would be supported by the evidence that brand awareness positively affected brand image in consumer goods products (Angel \& Manuel, 2005; Esch et al., 2006).

Aaker (1996) discovered that brand awareness was an important component of brand equity; it referred to the brand salience that existed in consumers' memories. Recall, recognition, brand dominance, top-of-mind, brand opinion and brand knowledge were differences in the level of brand awareness. Brand awareness was essential in building brand equity, according to Aaker (1991). Brand awareness contributed brand equity creation in four main ways. Firstly, it created a brand node in the consumer's memory. Secondly, it provided a sense of brand popularity in the consumer's mind. Thirdly, it acted as a signal of trust in the brand. Lastly, it gave enough reasons for the consumer to consider the brand in his consideration set.

Even though brand awareness was a vital component of brand equity, as discussed above, empirically it did not show direct causal effect on brand equity or brand loyalty. This could be supported by Rosa and Riquelme's (2008) online study that brand awareness did not show positive effects on brand equity. This result was consistent with Tong and Hawley's (2009) findings that brand awareness alone could not guarantee the success of brand equity in the sportswear market. Moreover, Wang, Wei, and Yu (2008) advocated that brand resonance, which was brand loyalty in terms of the firms perspective (Keller, 2001), did not support the hypothesis that related positively to the extent to which brand awareness was evident in the global brand equity model. 
Conversely, Gil et al. (2007) empirically proved that brand awareness positively affected brand loyalty and brand equity in a study of frequently consumed product. However, there were only two measured variables that existed in the construct. Most of the measured variables were deleted in order to satisfy the statistical result. As a conclusion, previous studies concretely supported that brand awareness would lead to better perceived quality, brand familiarity, and brand image. However, brand awareness did not show consistency of a positive effect toward brand loyalty and equity. Therefore, the following propositions could be formulated:

P1: The higher the awareness of a brand, the greater the perceived quality.

P2: The higher the awareness of a brand, the greater the brand familiarity.

P3: $\quad$ The higher the awareness of a brand, the greater the brand image.

\section{Brand Familiarity}

Researchers suggested that consumers evaluated brand more positively when they were familiar with it, therefore created favorable images of the familiar brand (Holden \& Vanhuele, 1999; Janiszewski, 1993). As referred to Keller (1993), brand attributes was one of the components of brand image. Ho and Chong (2003) had suggested that the level of brand familiarity and consumption experiences influenced consumers toward brand attributes. For this reason, consumers individually assessed each descriptive feature that characterizes a product or service based on the familiarity and experience they had with a certain brand. Consequently, the higher the level of brand familiarity would lead to better evaluation of brand attributes, which ultimately contributed to higher level of brand image.

The above statement was supported by Zajonc and Markus' (1982) study which proposed that familiarity may direct consumers to have favorable evaluations of a service or brand. When a consumer was confronted with a familiar brand, he or she felt emotional closeness and confidence. Subsequently, this increased the level of consumer experience and positively affected the brand image formation process. Woodward (2000) further highlighted that brand familiarity had significantly affected service products more than physical goods because of the complicated characteristics of services. Campbell and Keller (2003) advocated that increasing brand familiarity through accumulated customer experiences not only created a knowledge structure for the consumer, but also built up confidence about the brand, which caused positive brand evaluation and finally had an effect on brand trust (Sen \& Johnson, 1997; Zajonc \& Markus, 1982). Therefore, this study posited the following proposition:

P4: $\quad$ The higher the familiarity of a brand, the greater the brand image.

P5: $\quad$ The higher the familiarity of a brand, the greater the brand trust.

\section{Perceived Quality}

According to Gil et al. (2007), brand loyalty had been considered as a construct proceeded by the other three dimensions - brand awareness, brand association, and perceived quality. In order to establish this causal order, Chiou et al. (2002) had based their arguments on a cognitive-affective-behavioral hierarchical model. Thus, perceived quality was considered as a cognitive construct which resulted in affective response toward the brand. This effective response determined that the consumer behavior had lead to product purchase and brand loyalty. Roberts et al. (2004) turned to the purchase decision stages to justify a causal order between perceived quality and loyalty. Thus, perceived quality would be related to the information evaluation stage and loyalty which would be mainly related to the purchase decision stage.

The study of Gil et al. (2007) showed that perceived quality was positively related to brand loyalty and brand equity. However, Tong and Hawley (2009) indicated that perceived quality did not positively relate to brand equity. They further explained that just maintaining high quality or awareness of the brand was not adequate in ensuring the successfulness of a brand in the sportswear industry. As a result, perceived quality alone was not sufficient in securing overall brand equity; consequently, brand loyalty could only serve as a preceded construct of perceived quality and not as a mediating variable.

According to brand knowledge (Keller, 1993), good evaluation of perceived quality increased brand association. This was because when there was a good perception of quality, a positive brand image would be created 
as there is strong, favorable, and unique associations linked to the brand due to greater brand attributes, benefits, and attitudes as perceived by consumers. This can be supported by Kayaman and Arasli's (2007) study, which indicated that tangibility, reliability and empathy (perceived quality in service industry) showed positive effects on brand image in a hotel study. Thus, this study derived the following propositions:

P6: $\quad$ The higher the perceived quality of a brand, the greater the brand image.

P7: $\quad$ The higher the perceived quality of a brand, the greater the attitudinal brand loyalty.

\section{Brand Image}

With brand image being advantageous to companies, it was also a strong dominant factor in the level of consumer trust. Lehu (2001) confirmed that corporate image was a leading cause of high level of consumer trust. Likewise, in the retail setting, Esch et al. (2006) had confirmed the direct impact of brand image on a consumer's brand trust and the direct and indirect influence of brand image on current and future purchases. Additionally, the result of Yoon's (2002) study explained the significant influence of variables related to corporate image on consumers' trust towards a specific website. In addition, a financial study stressed that image was one of the fundamentals in building a sincere relationship of trust between customer satisfaction and loyalty (Flavian et al., 2006). Once customers had favorable images toward a certain brand, then this process would have a positive influence on the customer's trust and eventually reinforce their loyalty (Back, 2005; Kandampully \& Suhartanto, 2000; Kandampully \& Hu, 2007). Therefore, this study proposed the following propositions:

P8: $\quad$ The higher the image of a brand, the greater the brand trust.

P9: The higher the image of a brand, the greater the attitudinal brand loyalty.

\section{Brand Trust}

A consumer's trust toward a certain brand could lead to attitudinal brand loyalty. Trust had been at the centre of studies that aimed to explain loyalty. According to Pitta et al. (2006), in a perfect world, trust was unnecessary, but in the real world, it reduced the perceived risk by decreasing the possibility of incurring a loss. As a result, Rauyruen and Miller (2007) argued that in order to gain loyalty of customers, one must first gain their trust. Furthermore, based on the commitment-trust theory of relationship marketing (Morgan \& Hunt, 1994), brand trust had been recognized as a prominent variable leading to long-term relationships with customers, which in turn affected brand loyalty in a positive way (Chiou \& Droge, 2006; Flavian et al., 2006; Sichtmann, 2007; Martzler et al., 2008).

The relationship between consumer trust and loyalty had been supported in several studies (Morgan \& Hunt, 1994; Mayer et al., 1995; Harris \& Goode, 2004). Finally, Chiou and Droge (2006) indicated that trust had a direct effect on attitudinal loyalty and an indirect one through satisfaction. Sichtmann (2007) suggested that trust had a substantial impact on consumer behaviors, such as the selection of existing and new products and the word-ofmouth about the brand to other customers. Moreover, there was mediating effect of brand trust and brand attachment, which led to future purchase in the retail setting (Esch et al., 2006).

All recent results are consistent with the previous study done by Chaudhuri and Holbrook (2001), which indicated that brand trust affected attitudinal brand loyalty. It was apparent that if one party trusted another, then there would be some form of positive behavioral intention, such as the intention to repurchase and to make recommendations to the other party (Lau \& Lee, 1999). Aaker (1996) also declared that brand trust went beyond the consumer's satisfaction by way of functional performance of the product and its attributes. In conclusion, brand trust was the key variable to maintain continuing relationships with customers, which sequentially led to attitudinal brand loyalty (Matzler, 2008). Thus, the following proposition was derived:

P10: The higher the trust of a brand, the greater the attitudinal brand loyalty. 


\section{FAST FOOD BRAND EQUITY FRAMEWORK}

The propositions outlined above are graphically illustrated in Figure 1. This model was conceptualized using psychological-based approaches of brand equity and supported by the grounded theory of Aaker's brand equity. Although Aaker (1991) and Keller (1993) conceptualized brand equity differently, both defined brand equity from a customer perspective and emphasized that consumer-based brand equity provided value to the firm and to the customer. Muller and Woods (1994) pointed out the importance of restaurant brand management instead of product management. He proposed a clear concept of restaurant, development of brand image, and dependability of brand name. As a result, brand association was replaced by brand image. Furthermore, brand image was widely used in the hospitality industry as compared to brand association (Henry, Catherine \& Ada, 2010; Kayaman \& Arasli, 2007; Kim \& Kim, 2004).

As referred to consumers' brand knowledge, Alba and Hutchinson (1987) indicated that brand personality assessments were expected to be affected by consumers' knowledge and familiarity. Furthermore, Aaker (1996) argued that brand recognition reflected familiarity and linking acquired from past exposure. Thus, it was safe to include brand familiarity as a dimension of consumer-based brand equity on Aaker's concept. Lastly, brand trust was integrated, as indicated by Lassar, Mittal \& Sharma's (1995) trustworthiness.

There are two perspectives of brand loyalty - behavioral brand and attitudinal brand. Behavioral brand loyalty focuses on a consumer's actual purchase behavior of a certain brand over time (Ehrenberg \& Goodhardt, 2000), attitudinal brand loyalty centers on consumer's commitment toward a certain brand, and it represents a favorable attitude toward a specific brand in a chain of cognition, affection, and conation (Oliver, 1997). Hence, attitudinal brand loyalty was adapted because it was based on consumers' emotional commitments (psychologicalbased) rather than consumers' actual purchase behaviors.

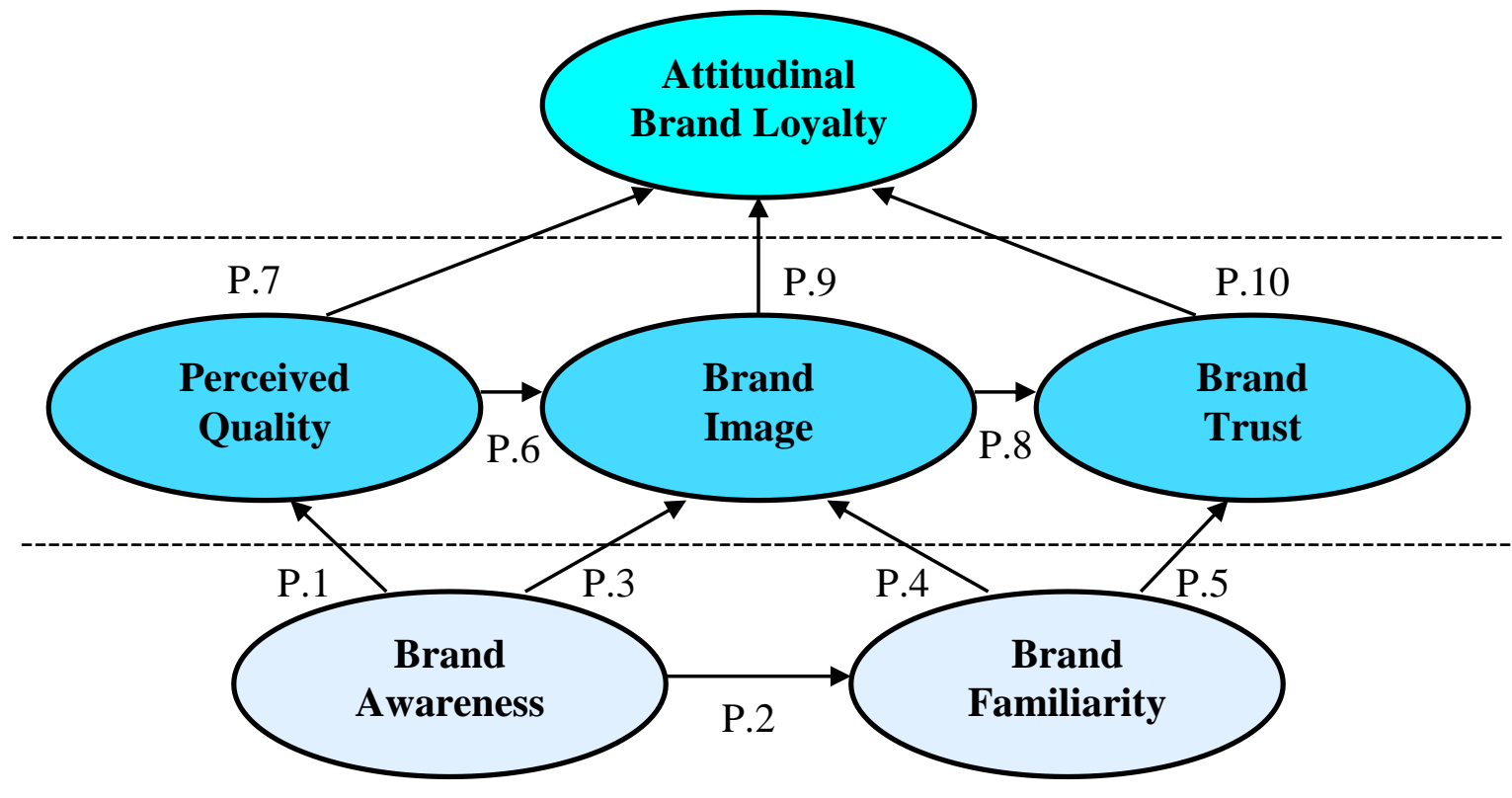

Figure 1: Fast Food Brand Equity Framework 
Fast food brand equity could be described by three levels of a hierarchical chain. The fundamentals for the next levels were brand familiarity and brand awareness (Heding, Knudtzen \& Bjerre, 2009). Moreover, brand awareness was presented as crucial to brand knowledge (Hoyer \& Brown, 1990). Remarkably, brand familiarity, perceived quality, brand image, and brand trust played mediating roles in the relationship between other dimensions. For instance, brand image served as a mediating variable between perceived quality and attitudinal brand loyalty, and brand image engaged a mediating character in the relationship between brand familiarity and brand trust.

\section{THEORETICAL CONTRIBUTIONS}

This study highlighted three important contributions in brand equity. Firstly, it explained the relationship between brand and customers (Fournier, 1998). The existence of brand relationship enabled the fast food brand to mitigate consumers' negative perceptions while making fast food purchase decisions. Alba and Hutchinson (1987) defined brand familiarity as the number of brand-related experiences that a consumer had built up. Thus, it not only emphasized on the total time spent processing information about the brand (Baker et al., 1986), but also indicated the direct and indirect knowledge available to the consumer (Alba and Hutchinson, 1987). Chaudhuri and Holbrook (2001) supported that consumers felt comfortable on trusted brands because trust increased their confidence level in the uncertain environment. Based on the commitment-trust theory of Morgan and Hunt (1994), it was obvious that trust was a key factor in collaborative relationships with customers in business marketing (Lau and Lee, 1999).

Secondly, this study aimed to extend Aaker's model by decomposing brand familiarity and brand trust based on theory of Keller (1993) and Lassar, Mittal and Sharma (1995). Brand familiarity is operationally referred to as the cognitive representations of experiences stored in memory, as well as prior experience with a brand, and cognitive representations of experiences with a brand that were organized in the memory as a structure or schema in the form of representations of brand names, attributes, uses, choice criteria and so on (Marks \& Olson, 1981). Brand trust was operationally defined as a feeling of security held by the consumer in his or her interaction with the brand, such that it was based on the perceptions that the brand was reliable and responsible for the interest and welfare of the consumer (Morgan \& Hunt, 1994).

Thirdly, this study attempted to fill the gaps in research by demonstrating a comprehensive set of casual relationships among brand equity dimensions at the customer level. These purposeful postulations served as an important research in identifying a hierarchical chain that existed in brand equity dimensions. This study intended to transform the research idea of consumer-based brand equity pyramid as proposed by Keller (2001). According to Keller's theory, the fundamental of attaining the right brand identity required building brand salience with consumers, and brand salience was referred to as the aspect of brand awareness (Keller, 2001). Brand awareness was the capability of a prospect buyer to recognize or recall a particular brand when in the selection process of certain categories of a product (Aaker, 1991). Brand recognition reflected familiarity and linking acquired from past exposure (Aaker, 1996). The next block of Keller's pyramid contained brand performance, imagery, judgments, and feelings, which could be referred to perceived as quality, brand image and brand trust in current framework, serving as appropriate steps in creating brand meaning and exciting brand response. As a result, it enhanced generalizability of the conceptual framework of consumer-based brand equity.

\section{MANAGERIAL IMPLICATIONS}

Practitioners must be cautious with the hierarchical chain of consumer-based brand equity. According to Heding, Knudtzen, and Bjerre (2009), brand awareness was a prerequisite for consumer-based brand equity. If the consumer was not aware of the brand, it was not relevant to talk about brand equity in the first place; then the company competed on the product rather than the brand. As a result, fast food managers should focus on event promotions, sponsorship, publicity, sampling, and other attention-getting approaches of marketing activities. Besides, the brand must not only be "top of mind" and have sufficient "mind share", it must also do so at the right time and place. For many brands, the key question was not whether or not customers can recall the brand, but rather where and when they thought of the brand and how easily and how often they thought about that brand. Therefore, fast food managers should adopt a broad view of branding decision to make certain that the strength of a brand's presence was in the consumer's mind. 
With respect to familiarity of brand, practitioners needed to emphasize the amount of time spent in processing brand information. The greater the amount of time spent processing brand information, the greater the level of familiarity with that information, and higher the chances in promising value on brand trust and brand image. As for brand trust, fast food practitioners had to guarantee the consistency of operations, such as food portion, taste, presentation, promotion, services, business hours, environment, facilities, and food delivery time.

The contribution of branding strategy might have had direct and indirect results. For instance, although there was a direct effect of brand familiarity on brand trust, the indirect effect (with brand image playing a mediating role) might serve as a stronger driver for brand trust in the context of the fast food industry. Practically, perceived quality was measured as a "core or primary" facet across the food service industry. Practitioners must be able to identify which attributes consumers were looking for in regard to quality. However, fast food practitioners should also highlight the importance of other dimensions, especially brand familiarity and brand trust, in managing brand equity. Focusing solely on product attributes will definitely increase the risk of a product-attribute fixation trap. Thus, the spotlight of communication should be considered on brand personality, brand reliability, organizational associations, brand symbols, logo, character, packaging and slogan under different conditions.

In particular, fast food managers should decide the core needs and wants of consumers to be satisfied by the brand. This study assisted in answering how to overcome the complexity brand strategies and relationships, as defined by Aaker (1996), by demonstrating clear causal relationships among brand equity dimensions. By understanding and simplifying the branding strategy, fast food managers will have a clear brand management direction, especially in how to integrate communication and create relationship between the brand and the fast food firm. Effectiveness of the integration between different marketing tactics, with the same strategic branding goal to produce manifold, links to core benefits, indirectly facilitating to create cohesive and consistent brand equity (Keller, 1993).

\section{CONCLUSIONS}

This study elaborated on the concept of brand equity and provided a fast food brand equity framework based on a comprehensive review of the existing empirical studies. Two additional dimensions - brand familiarity (cognitive representations of experiences stored in memory) and brand trust (confidence level) are included, which served as a function in mitigating consumers' negative perceptions during purchase decision or food selection. A proposed conceptual framework - hierarchical chain of consumer-based brand equity based on the casual relationships among dimensions - was postulated. Brand familiarity, perceived quality, brand image, and brand trust were proposed to serve as mediating variables of other constructs, indicating direct and indirect relationships among brand equity dimensions.

\section{FUTURE RESEARCH}

Examination of the brand equity literature in this study helped to develop a fast food brand equity framework that called upon further empirical data to verify its propositions. There were also two additional dimensions proposed. Future research may identity more relevant dimensions which serve as important brand relationship roles. According to a consumer-based brand equity pyramid proposed by Keller (2001), there were more details of brand-building blocks. For instance, feeling block covered warmth, fun, excitement, security, social approval, and self-respect instead of purely on trust. Furthermore, this study only centered on intensity of brand relationship (attitudinal brand loyalty) and did not cover activity of brand relationship. Lastly, the casual relationships among dimensions of brand equity were derived from extensive reviews of previous empirical studies, based on different industries as there are a limited number of studies focused on fast food brand equity. Consequently, there is the possibility of omission or over-coverage for the casual relationships presented in the proposed model, which might affect the true picture of the hierarchical chain. 


\section{AUTHOR INFORMATION}

Tan Teck Ming (Degree from Multimedia University) is an assistant lecturer at Centre for Diploma Programmes, Multimedia University, Melaka Campus, Malaysia. His research interests include brand equity, online branding, advertising, financial services and consumer research. E-mail: tmtan@mmu.edu.my.

Hishamuddin Ismail (Phd in Marketing), he is an associate professor/dean at Faculty of Business and Law, Multimedia University, Melaka Campus, Malaysia. His research interests are in customer loyalty/satisfaction, customer relationship marketing/management, and internet marketing. He has published in Journal of Information and Knowledge Management, The Journal of Information and Knowledge Management Systems, the Business Renaissance Quarterly, International Journal of Commerce and Management, International Journal of Electronic Customer Relationship Management, The Journal of American Academy of Business and Journal of Targeting, Measurement and Analysis for Marketing (UK). E-mail: hisham@mmu.edu.my.

Devinaga Rasiah (Phd in Banking and Finance), her MBA is from University of Wales, UK. She is a lecturer at Faculty of Business and Law, Multimedia University, Melaka Campus, Malaysia. Her research interests are in commercial and investment banking. Apart from these, she is also interested in topics relating to internal controls, bank profitability, E-finance, Automated Teller Machine services and self service technologies at commercial banks. She has published in academic journals such as European Journal of Economics, Finance and Administrative Sciences, Journal of Information and Knowledge Management and Journal of Performance Management. E-mail: devinaga.rasiah@mmu.edu.my.

\section{REFERENCES}

1. $\quad$ Aaker, D. A. (1991), "Managing brand equity", New York: Free Press.

2. Aaker, D. A. (1996), "Measuring brand equity across products and markets", New York: Free Press.

3. Agarwal, M. K., \& Rao, V. (1996), "An empirical comparison of consumer based measures of brand equity", Marketing Letters, Vol. 7 No. 3, pp. 237-247.

4. Alba, J. W. \& Hutchinson, J. W. (1987), "Dimensions of consumer expertise", Journal of Consumer Research, Vol. 13, pp. 411-454.

5. Angel, F.V.-R. \& Manuel, J.S.-F. (2005), "The impact of marketing communication and price promotion on brand equity", The Journal of Brand Management, Vol. 12 No. 6, pp. 431-44.

6. Back, K. J. (2005), "The effects of image congruence on customers' brand loyalty in the upper middle-class hotel industry", Journal of Hospitality \& Tourism Research, Vol. 29 No.4, pp. 448-467.

7. Baker, W. J., Hutchinson, W., Moore, D., \& Nedungadi, P. (1986), "Brand familiarity and advertising: effects on the evoked set and brand preferences", Advances in Consumer Research, Vol. 13, pp. 637-642.

8. Barton, A. W. \& Robin, W. (2002), "Handbook of marketing", London, SAGE publications Ltd.

9. Campbell, D. T. \& Fiske, D. W. (1959), "Convergent and discriminate validation by the multitraitmultimethod matrix", Psychological Bulletin, Vol. 56 No. 2, pp. 81-105.

10. Campbell, M.C. \& Keller, K. L. (2003), "Brand familiarity and advertising repetition effects", Journal of Consumer Research, Vol. 30 (September), pp. 292-304.

11. Chaudhuri, A. \& Holbrook, M. B. (2001), "The chain of effects from brand trust and brand affect to brand performance: the role of brand loyalty", Journal of Marketing, Vol. 65, April, pp. 81-93.

12. Chiou, J. S., Droge, C. \& Hanvanich, S. (2002), “Does customer knowledge affect how loyalty is formed?”, Journal of Services Research, Vol. 5 No. 2, pp. 113-25.

13. Chiou, J.S. \& Droge, C. (2006), "Service quality, trust, specific asset investment, and expertise: direct and indirect effects in a satisfaction-loyalty framework", Journal of the Academy of Marketing Science. Vol. 34 No. 4, pp. 613-627.

14. Clarke, S. (2003), "Closing the deal: GM's marketing dilemma and its franchised dealers", Business History, Vol. 45 No. 1, pp. 60-79.

15. Cobb-Walgren, C. J., Beal, C., \& Donthu, N. (1995), "Brand equity, Brand preferences, and purchase intent", Journal of Advertising, Vol. 24 No. 3, pp. 25-40.

16. D'Souza, G. \& Rao, R. C. (1995), "Can repeating an advertisement more frequently than the competition affect brand preference in a mature market?”, Journal of Marketing, Vol. 59 No. 2, pp. 32-47. 
17. Dacin, P.A. \& Smith, D.C. (1994), "The effect of brand portfolio characteristics on consumer evaluations of brand extensions", Journal of Marketing Research, Vol. 31 No. 2, pp. 229-242.

18. Daily mail (2010), "Ban on takeaway too close to school" Available at: http://proquest.umi.com/pqdweb?index $=2 \&$ did $=2171972131 \&$ SrchMode $=1 \&$ sid= $=1 \&$ Fmt $=3 \&$ VInst=PROD $\&$ VType $=$ PQD\&RQT $=309 \&$ VName $=$ PQD $\& T S=1288065853 \&$ clientId=24792, Retrieved 27 October 2010.

19. Datamonitar (2009), "Fast Food: Global Industry Guide" Available at: http://www.researchandmarkets.com/reports/c71910, Retrieved 22 September 2010.

20. Delgado-Ballester, E., \& Munuera-Aleman, J. L. (2005), "Does brand trust matter to brand equity" Journal of Product \& Brand Management, Vol. 14 No. 3, pp. 187-196.

21. Dodds, W. B., Monroe, K. B., \& Grewal, D. (1991), "Effects of price, brand, and store information on buyers' product evaluations", Journal of Marketing Research, Vol. 28 No. 3, pp. 307-319.

22. Ehrenberg, A. \& Goodhardt G. (2000), "New brands: near-instant loyalty", Journal of Marketing Management, Vol. 16 No. 6, pp. 607-617.

23. Erdem, T. \& Swait, J. (1998), "Brand equity as a signaling phenomenon", Journal of Consumer Psychology, Vol. 7 No. 2, pp. 131-157.

24. Esch, F. R., Langner, T., Schmitt, B.H., \& Geus, P. (2006), "Are brands forever? How brand knowledge and relationships affect current and future purchases" Journal of Product \& Brand Management, Vol. 15 No. 2, pp. 98-105.

25. Farquhar, P. H., Han, J. Y. \& Ijiri, Y. (1991), "Recognizing and measuring brand assets", Marketing Science Institute Working Paper Series, Report No. 91-119, Marketing Science Institute, Cambridge, MA.

26. $\quad$ Feldwick, P. (1996), "Do we really need brand equity?", The Journal of Brand Management, Vol. 4 No. 1, pp. 9-28.

27. Flavián, C., Guinalíu, M., \& Gurrea, R. (2006), "The role played by perceived usability, satisfaction and consumer trust on website loyalty" Information and Management, Vol. 43 No. 1, pp. 1-14.

28. Flavián, C., Guinalíu, M., \& Gurrea, R. (2006), "The role played by perceived usability, satisfaction and consumer trust on website loyalty", Information and Management, Vol. 43 No. 1, pp. 1-14.

29. Gil R. B., Andre's E. F. \& Salinas E. M. (2007), "Family as a source of consumer-based brand equity", Journal of Product \& Brand Management, Vol. 16 No. 3, pp. 188-199.

30. Grewal, D., Krishnan, R., Baker, J., \& Borin, N. (1998), "The effect of store name, brand name, and price discounts on consumer's evaluations and purchase intentions" Journal of Retailing, Vol. 74 No. 3, pp. 331352.

31. Gursoy, D. \& McCleary, K. W. (2004), "Travelers' prior knowledge and its impact on their information search behavior", Journal of Hospitality \& Tourism Research, Vol. 28 No. 1, pp. 66-94.

32. Harris, L. \& Goode, M. (2004), "The four level of loyalty and the pivotal role of trust: a study of online services dynamic", Journal of Retailing, Vol. 80 No. 2, pp. 139-58.

33. Henry T., Catherine C., \& Ada L. (2010), "An exploratory study of the relationship between customerbased casino brand equity and firm performance." International Journal of Hospitality Management, Vol. 29 , pp. $754-757$.

34. Ho, T. \& Chong, J. (2003), "A parsimonious model of stockkeeping-unit choice", Journal of Marketing Research, Vol. 40 (August), pp. 351-365.

35. Holden, S. J. S. \& Vanhuele, M. (1999), "Know the name, forget the exposure: brand familiarity versus memory of exposure context", Psychology \& Marketing, Vol. 16 No. 6, pp. 479-496.

36. Hoyer, W. D. \& Brown, S. P. (1990), "Effects of brand awareness on choice for a common, repeatpurchase product", Journal of Consumer Research, Vol. 17 No. 2, pp. 141-8.

37. Janiszewski, C. (1993), "Preattentive more exposure effects", Journal of Consumer Research, Vol. 20 No. 3, pp. 376-392.

38. Kamakura, W. A. \& Russell, G. J. (1993), "Measuring brand value with scanner data", International Journal of Research in Marketing, Vol. 10 No. 1, pp. 9-21.

39. Kandampully, J. \& Hu, H. (2007), "Do hoteliers need to manage image to retain loyal customer?" International Journal of Contemporary Hospitality Management, Vol. 19 No. 6. pp. 435-443.

40. Kandampylly, J. \& Suhartanto, D. (2000), " Customer loyalty in the hotel industry: the role of customer satisfaction and image", International Journal of Contemporary Hospitality Management, Vol.12 No. 6, pp. 346-351. 
41. Kayaman R. \& Arasli H. (2007), "Customer based brand equity: evidence from the hotel industry", Managing Service Quality, Vol. 17 No. 1, pp. 92-109.

42. Keller, K. L. (1993), "Conceptualizing, measuring, and managing customer-based brand equity", Journal of Marketing, Vol. 57 No. 1, pp. 1-22.

43. Keller, K.L. (2001), "Building customer-based brand equity". Marketing Management, Vol. 10 No. 2, pp. 15-19.

44. Kim, H. \& Kim, W. G. (2005), "The relationship between brand equity and firms' performance in luxury hotels and chain restaurants", Tourism Management, Vol. 26, pp. 549-560.

45. Laroche M., Toffoli, R., Kim, C., Muller, T.E. (1996), "The influence of culture on pro-environmental knowledge, attitudes, and behaviors: a Canadian perspective", in Corfman, K.P., Lynch, J.G.

(Eds),Advances in Consumer Research, Association for Consumer Research, Provo, UT, Vol. 23, pp.196202.

46. Lassar, W., Mittal, B. \& Sharma, A. (1995), "Measuring customer-based brand equity", Journal of Consumer Marketing, Vol. 12 No. 4, pp. 11-19.

47. Lau, G.T., \& Lee, S.H. (1999), "Consumers' trust in a brand and the link to brand loyalty", Journal of Market-Focused Management, Vol. 4 No. 4, pp. 341-370.

48. Lehu, J-M. (2001), "Fidelizar al Cliente", Piano's, Barcelona.

49. Leung, L. C, \& Bougoure, Ursula-Sigrid. (2008), "The effects of brand relationship on brand consideration and brand equity for services", Proceedings, Australia \& New Zealand Marketing Academy Conference (ANZMAC), University of Western Sydney, Sydney, December.

50. Loken, B., \& Roedder J. D. (1993), "Diluting brand beliefs: When do brand extensions have a negative impact?" Journal of Marketing, Vol. 57 No. 3, pp. 71-84.

51. Macdonald, E. \& Sharp, B. (2000), "Brand awareness effects on consumer decision-making for a common, repeat-purchase product: a replication", Journal of Business Research, Vol. 48 No. 1, pp. 5-15.

52. Mano, H. \& Davis, S. M. (1990), "The effects of familiarity on cognitive maps". Advances in Consumer Research, Vol. 17, pp. 275-282.

53. Marks, L. \& Olson, J. (1981), "Toward a cognitive structure conceptualization of product familiarity", Advances in Consumer Research, Vol. 8 No. 1, pp. 145-150.

54. Matzler, K., Grabner-Krauter, S., \& Bidmon, S. (2008), "Risk aversion and brand loyalty: the mediating role of brand trust and brand affect" Journal of Product \& Brand Management, Vol. 17 No.3, pp. 154-162.

55. Matzler, K., Grabner-Krauter, S., \& Bidmon, S. (2008), "Risk aversion and brand loyalty: the mediating role of brand trust and brand affect" Journal of Product \& Brand Management, Vol. 17 No. 3, pp. 154-162.

56. Mayer, R., Davis, J. \& Schoorman, D. (1995), “An integrative model of organizational trust", Academy of Management Review, Vol. 20 No. 3, pp. 709-34.

57. Morgan, R. M. \& Hunt, S. D. (1994), "The commitment-trust theory of relationship marketing", Journal of Marketing, Vol. 58No. 3, pp. 20-38.

58. Morgan, R. M., \& Hunt, S. D. (1994), "The commitment-trust theory of relationship marketing" Journal of Marketing, Vol. 58 No. 3, pp. 20-38.

59. Muller, C. C., \& Woods, R. H. (1994), "An expected restaurant typology", Cornell Hotel and Restaurant Administration Quarterly, Vol. 35 No. 3, pp. 27-37.

60. Oliver R. L. (1997), "Satisfaction: A behavioral perspective on the consumer", New York: McGraw-Hill.

61. Park, C. S. \& Srinivasan, V. (1994), "A survey-based method for measuring and understanding brand equity and its extendibility", Journal of Marketing Research, Vol. 31, pp. 271-288.

62. Petty, R. E., \& Cacioppo, J. T. (1986a), "Communication and persuasion: Central and peripheral routes to attitude change", New York: Springer-Verlag.

63. Pitta, D., Franzak, F. \& Fowler, D. (2006), “A strategic approach to building online customer loyalty: integrating customer profitability tiers", Journal of Consumer Marketing, Vol. 23 No. 7, pp. 421-9.

64. Rangaswamy, A., Burke, R., \& Oliva, T. A. (1993), "Brand equity and the extendibility of brand names", International Journal of Research in Marketing, Vol. 10 No. 1, pp. 61-75.

65. Rao, A. R. \& Monroe, K.B. (1989), "The effect of price, brand name, and store name on buyers' perceptions of product quality: an integrative review", Journal of Marketing Research, Vol. 26, August, pp. 351-7.

66. Rauyruen, P. \& Miller, K. (2007), "Relationship quality as a predictor of B2B customer loyalty", Journal of Business Research, Vol. 60 No. 1, pp. 21-31. 
67. Reynolds, T. \& Olson, J. (1995), "Identifying a brand's key equities", Marketing Science Institute Working Paper Series, Report No. 95-111, Marketing Science Institute, Cambridge, MA.

68. Roberts, J., Morrison, P., Chandrashekaran, M. \& Gordon, A. (2004), "Measuring sources and outcomes of brand equity", Communication in ANZMAC Conference .(Australian and New Zealand Marketing Conference), proceedings: available at: http://130.195.95.71:8081/WWW/ANZMAC2004/CDsite/papers/Roberts1.PDF

69. Rosa R. E. \& Riquelme H. E. (2008), "Brand equity for online companies." Marketing Intelligence \& Planning, Vol 26, No. 7, pp. 719-742.

70. Russell-Bennett, R., McColl-Kennedy, J. R., \& Coote, L. V. (2007), "Involvement, satisfaction, and brand loyalty in a small business services setting", Journal of Business Research, Vol. 60 No. 12, pp. 1253-1260.

71. Rydell, S. A., Harnack, L. J., Oakes, J. M., Story, M., Jeffery, R. W. \& French, S. A. (2008), "Why eat at fast-food restaurants: Reported reasons among frequent consumers", Journal of the American Dietetic Association, Vol. 108 No. 12.

72. Schlosser, E. (2002), "Fast Food Nation: The bitter truth about fast food". Available at: http://www.spiritouch.com/en/pdfs/FastFoodNation.pdf, Retrieved 1 December 2010.

73. Sen, S., \& Johnson, E. J. (1997), "Mere-possession effects without possession in consumer choice" Journal of Consumer Research, Vol. 24 No. 2, pp. 105-17.

74. Sharma, S. (2007), "Fast-Food Branding Influences Preferences." Available at: http://www.insidermedicine.com/archives/Fast-Food_Branding_Influences_Preferences 1445.aspx, Retrieved 1 December 2010.

75. Sichtmann, C. (2007), "An analysis of antecedents and consequences of trust in a corporate brand", European Journal of Marketing, Vol. 41 No.9-10, pp. 999-1015.

76. Singh, D. (2007), "Fast-food ads banned from kids' shows." Available at: http://thestar.com.my/news/story.asp?file=/2007/6/23/nation/18109396\&sec=nation, Retrieved 1 December 2010.

77. Smith, R. E. (1993), "Integrating information from advertising and trial: Processes and effects on consumer response to product information," Journal of Marketing Research, Vol. 30, pp. 204-219.

78. Srivastava, Rajendra, \& Shocker, Allan D. (1991), "Brand equity: A perspective on its meaning and measurement" Marketing Science Institute Working Paper Series, Report No. 91-124, Marketing Science Institute, Cambridge, MA.

79. Tong, X. \& Hawley, J. M. (2009), "Measuring customer-based brand equity: empirical evidence from the sportswear market in China." Journal of Product \& Brand Management, Vol. 18 No. 4, pp. 262-271.

80. Wang H. Z., Wei, Y. J. and Yu, C. L. (2008), "Global brand equity model: combining customer-based with product-market outcome approaches", Journal of Product \& Brand Management, Vol. 17, No. 5, pp. 305316.

81. William D. N. (2000), "Branding in the third millennium", Marketing Management, Vol. 9, No. 2 (Summer), pp. 64.

82. Woodward, T. (2000), "Using brand awareness and brand image in tourism channels of distribution", Journal of Vacation Marketing, Vol. 6 No. 2. pp. 119-130.

83. Yoo, B., Donthu, N. \& Lee, S. (2000), "An examination of selected marketing mix elements and brand equity", Academy of Marketing Science, Vol. 28 No. 2, pp. 195-212.

84. Yoo, B. \& Donthu, N. (2001), "Developing and validating a multidimensional consumer-based brand equity scale", Journal of Business Research, Vol. 52 No. 1, pp. 1-14.

85. Yoon, S. J. (2002), "The antecedents and consequences of trust in online-purchase decisions" Journal of Interactive Marketing, Vol. 16 No. 2, pp. 47-63.

86. Zajonc, R. B. \& Markus, H. (1982), "Affective and cognitive factors in preferences" Journal of Consumer Research, Vol. 9 (September), pp. 123-131. 
NOTES 